\title{
Dual candidacy as a source of legislator behaviour. The re-election and the mandate incentive under mixed-member electoral rules
}

\begin{abstract}
Legislators are often viewed as 'single-minded seekers of re-election', and hence their actions are attributed to their ultimate goal of staying in office. However, an alternative approach 'liberates' legislators from the ever continuing struggle for re-election and argues that MPs carry out certain tasks simply because it is part of their jobs. This study is an attempt to empirically separate re-election and mandate incentives in the MPs' behaviour. Hungary's mixed-member electoral system with dual candidacy creates a situation in which the two types of incentives can be separately observed. If mandate incentives prevail there should be a difference between SMD and list MPs, while re-election motivations offer the dominant explanation to MP behaviour if the difference is between MPs nominated in SMDs and those who are not. Analysing legislators' attitudes and behaviour between 2010 and 2014 it is found that although re-election incentives indeed prevail in the MPs' behaviour, the effect of the mandate strongly characterizes attitudes creating a tension between what MPs do and what they think they should be doing.
\end{abstract}

\section{Keywords}

Legislators, Parliament, Electoral rules, Hungary, Constituency orientation, Voting dissent

\section{Conflict of interest}

The author declares no conflict of interest 


\section{Introduction}

When studying the determinants of representational roles and legislator behaviour, scholars very often turn to electoral rules as the most important explanatory factor. Building on the article of Carey and Shugart (1995) numerous empirical work demonstrate a connection between electoral systems and work in the constituency (Lundberg 2006), pork barrel politics (Stratmann and Baur 2002), representational attitudes (Heitshusen, Young, and Wood 2005; Pilet, Freire, and Costa 2012), legislative (Bräuninger, Brunner, and Däubler 2012; Erik S. Herron 2002) and non-legislative (Manow 2013) parliamentary work. The overarching hypothesis of the literature is that candidate-centred electoral rules encourage personalised representation and constituency orientation, whereas party-centred rules provide incentives for the representation of party interests.

Legislative scholars often argue that legislators strategically react to electoral rules in a way that maximizes their chances of re-election. The re-election incentive is viewed the main catalyst for the forming of representational roles, and legislators are labelled as 'singleminded seekers of re-election' (Mayhew 1974). Nevertheless, an alternative approach 'liberates' legislators from the ever continuing struggle for re-election and argues that Members of Parliament (MPs) carry out certain tasks simply because it is part of their jobs. For instance, legislators elected in single-member districts (SMDs) adopt constituency service, because it is considered as part of the job (henceforth the mandate incentive). The mandate incentive is thus qualitatively different from the re-election incentive: MPs act the way they do primarily because of what is in their 'job descriptions', and not because they want to be re-elected. These 'job descriptions' are crafted by both voters and parties. 
At this point, it seems that both the re-election and the mandate incentives lead to the same outcome: no matter which type of incentives shape their behaviour SMD MPs are always more constituency oriented, while list MPs follow the party line. This eventually makes it difficult to empirically identify and separate the two incentives. One of the consequences of this is that most of the time, when presenting evidence on the effect of electoral rules on representational roles and legislator behaviour, we are only able to guess the causal mechanism. Building on the professionalization of politics, i.e. the fact that the legislators' livelihood depends on re-election, the majority of authors prefers the re-election inventive as the main explanatory mechanism. But are they right to do so? The primary aim of this article is to find out how legislators accommodate these two incentives - incentives generated by their mandates and their re-election seeking - in their role perceptions and behaviour.

In order to separate the re-election and the mandate incentives, one needs an electoral system, in which these two types of motivations do not always align. A mixed-member electoral system with dual candidacy represents a situation just like this. Legislators elected from party lists may pursue an SMD career, and thus adopt strategies different from what would logically follow from their positions as list MPs. If the behaviour of list MPs with SMD ambitions resembles that of SMD MPs, the re-election incentive is likely to play an important role, and the mandate divide (i.e. the difference between SMD and list MPs) diminishes. Similarly, if list MPs with SMD candidacy are more similar to list MPs without SMD nomination than to SMD MPs, mandate motivations dominate MP behaviour. To measure these two incentives, I use the Hungarian MP data from the 2010 wave of the Comparative Candidates Survey as well as legislator activity record from the 2010-2014 parliament. 


\section{The re-election and the mandate incentive}

\section{The re-election incentive}

Looking at legislator behaviour from the viewpoint of the re-election incentive, very simply put, MPs behave the way they do because they expect their actions to translate into a better chance at re-selection, and eventually, votes at the next elections (for a detailed overview of the argument see Papp and Russo 2018). Consequently, MPs look into the future when making decisions about splitting their resources between the various tasks (such as constituency service and representing party interests) in the present. Re-election and reselection tend to be negative political incentives: the cost of not meeting the expectations of the party and the voters is bad reputation, and ultimately, de-selection and failing at the next elections. The decision on what types of activities MPs should prioritize depends primarily on electoral rules.

One of the most frequently cited characteristics of single member majority systems is that it creates a strong linkage of accountability (Lancaster 1986; Mitchell 2000; Norris 2000; Scholl 1986), that makes re-election seekers more vulnerable to the pressure from the electorate (Cooper and Richardson 2006). MPs must carry out constituency service, stay visible, be responsive to constituent demand and represent the interests of their local voters.

Additionally, as voters can easily identify who to approach with their problems (Scholl 1986), and MPs are also better known by the electorate (Cooper and Richardson 2006), single member districts tend to generate larger demand for constituency service than multi-member districts (MMDs).

Contrarily, in MMDs with a geographical overlap among representatives (Heitshusen, Young, and Wood 2005) legislators can delegate problem-solving to other MPs (Gallagher and 
Holliday 2003), and thus the link of accountability becomes confused. In such systems, legislators are more accountable to the party selectorate than to the electorate (Norris 2004), which makes the contest for re-election a fight for higher positions on the party lists (Curtice and Shively 2009). Therefore, sometimes the re-election incentive aims at re-selection (Strøm 1997). Empirical evidence suggests that parties are indeed not blind to what MPs do, and MP behaviour very often translates to better re-selection chances (Baumann, Debus, and Klingelhöfer 2017; Borghetto and Lisi 2018; Däubler, Christensen, and Linek 2018; Marangoni and Russo 2018).

\section{The mandate incentive}

On the other hand, the selection model of representation, for instance, assumes that the main goal of legislators is to pursue good public policy, and voters choose representatives to act in their best interests independent of their desire to be re-elected (Fearon 1999; Mansbridge 2009). Thus, it is not only the re-election incentive motivating MPs to act on behalf of their districts, but constituency service may be considered as part of the job legislators carry out with no regard to the consequences. The feeling of responsibility for the voters is also part of the job perception, just as the satisfaction with a well-done job (Norton 2002). MPs may also enjoy working in the constituency more than they enjoy parliamentary work because they get an instant feedback about the quality of their work (Cain, Ferejohn, and Fiorina 1987). These feelings, perceptions and obligations are independent of the re-election incentive, and can be perceived as being related to the mandate.

One should not underestimate the importance of job descriptions and workplace norms. Being a legislator is like holding any other job: legislators have to engage in activities delegated to them, and which activities perhaps do not yield any advantages at the next elections. This is 
especially true in the case of legislators elected on closed party lists, where 'invisible' parliamentary work may be a priority over constituency representation (Papp 2019). Furthermore, as to constituency casework, comparative data suggests that, on average, being in touch with the voters' problems is a more important incentive to legislators than reselection and re-election when it comes to performing constituency service (see Figure 1).

[Figure 1 about here]

Although it is to assume that these two types of motivations drive MP role perceptions and behaviour at the same time, their relative weight may vary. In some cases, the re-election incentive is the dominant driving force of MP behaviour, while in others, the effect of the mandate is more pronounced. Nevertheless, the professionalization of politics makes the reelection incentive comparatively more important than motivations related to the mandate. If the representatives' daily living is dependent upon the choices they make as MPs (Mayhew 1974), they will probably act in the favour of whoever is in charge of the MPs' re-selection and re-election.

Mixed-member electoral systems: a laboratory for separating incentives

The re-election and the mandate incentives are both related to electoral rules. If MPs want to be (re-)elected in SMDs, they carry out constituency service, and are less party-centred, while such activities may be too costly for MPs who are elected from party lists, and do not want to compete in SMDs. Similarly, constituency service is part of the job for SMD MPs, whereas list MPs have weaker ties to the local level, and are expected to attend the party's business (Papp 2019). As being an SMD MP directs legislators toward constituency representation no 
matter if this is because of the re-election or the mandate incentive, the two effects are almost impossible to isolate. However, with the right combination of electoral system characteristics, the re-election and the mandate incentives may be empirically separated.

Mixed-member electoral systems are often used by researchers to test the effect of the electoral formula on MP roles and behaviour. It has been shown that mandate type affects MPs' perceptions of pork barrel allocation (Lancaster and Patterson 1990), role perceptions (Klingemann and Wessels 2001), office allocations (Pekkanen, Nyblade, and Krauss 2006), attitudes toward party discipline (Montgomery 1999) as well as the amount of district work (Bowler and Farrell 1993). As to the legislators' tendency to defect the party line at roll-call, Thames $(2001,2005)$ finds evidence for the mandate divide in the case of Russia's weakly institutionalized party system, but rejects the hypothesis in Hungary and Ukraine where parties are strong enough to enforce party unity (Thames 2005). However, despite the high levels of party system institutionalization, Sieberer (2010) shows that SMD MPs are indeed more likely to defect than list MPs in the German Bundestag, while Olivella and Tavits (2014) come to the same conclusion while analysing the case of Hungary.

Besides the mandate divide, students of mixed-member electoral rules often discuss cross-tier contamination, and identify two sources: (1) parties' decisions of entering the electoral arena which affects the number of competing parties (Cox and Schoppa 2002; Ferrara and Herron 2005; Eric S. Herron and Nishikawa 2001), and (2) candidate strategies that have consequences on the MPs' strategic behaviour (Bawn and Thies 2003; Crisp 2007; Thames 2005). From the viewpoint of this study, the second source of contamination is especially important. This type of contamination is often the reason why there is sometimes limited evidence for a mandate divide (Ishiyama 2000; Lundberg 2006; Morlang 1999): MPs elected 
in SMDs and party lists are more alike, than it would be suggested based on the attitudes and behaviour of MPs elected under pure majority or PR rules.

The degree of cross-tier contamination depends on dual candidacy (i.e. the candidates' ability to run on multiple tiers at the same time), and the parties' powers in influencing re-election. With regard to the former, list MPs who were defeated on the SMD tier may still act as 'shadows' of SMD MPs and carry out constituency service, which makes list MP 'move towards' SMD MPs in their role perceptions (Carman and Shephard 2007). In the latter case, when the re-election of the individual MPs heavily depends on the parties' support, however, SMD MPs show the same behavioural and attitudinal patterns than list members (Bawn and Thies 2003; Erik S. Herron 2002; Thames 2005). A good measure for the powers of the party is the candidate selection process. Centralized candidate selection strengthens the party's positions against individual MPs, while decentralization leaves a leeway for legislators in pursuing their own agendas.

\section{The empirical task of separating the re-election and the mandate incentive}

But how can we separate the re-election from the mandate incentives in a mixed-member electoral system? As a first step, important assumptions about the MPs' behaviour have to be made. First, it is to assume that MPs want to be re-selected and re-elected (Mayhew 1974). Second, MPs either want to keep their current mandate or obtain a more prestigious one. Third, SMD mandates are more prestigious than list mandates (Lundberg 2006; Ward 1998), as they often come with more money and resources. The consequence of these assumptions is that SMD MPs aim at defending their seats, while list MPs either want to continue on being list MPs or will go after one of the SMD mandates. Fourth, MPs formerly nominated in SMDs are expected to continue on pursuing this objective at the next elections (Carman and 
Shephard 2007; Zittel 2012). This means that former SMD candidacy is considered a proxy for MP preferences on their candidacy at the next elections.

Now, let us suppose that MPs may be nominated for types of seats different to which they are currently holding. Particularly important is the case of list MPs nominated in SMDs, which makes list MPs heterogeneous in terms of electoral incentives. The job description of list MPs does not include constituency service, but they may be electorally motivated to 'shadow' SMD MPs to stand a chance in the SMD at the next elections (Carman and Shephard 2007). In such a case, the re-election and the mandate incentives clearly contradict. By observing the behaviour of MPs in groups defined by the different combinations of mandate type and SMD candidacy, we are able to measure the two types of motivations separately.

Figure 2 presents a stylized picture of the expected results in two cases: strong mandate incentive and strong re-election incentive. The vertical axis represents the propensity of constituency orientation and voting dissent in parliament. The behaviour of three groups is visualized: (1) SMD MPs, (2) list MPs with SMD candidacy at the previous election, and (3) list MPs with no SMD candidacy. In the case of a strong mandate incentive (left panel), SMD nomination should not motivate constituency orientation and maverick behaviour at roll-call. Therefore, Group 2 MPs are expected to have similar behavioural patterns to Group 3 MPs, after all, they are all list MPs. Conversely, in the case of a strong re-election inventive (right panel), aiming at election in an SMD, Group 2 MPs appear as 'shadows' to Group 1 MPs by showing the same type of behaviour. The mandate incentive is the primary mechanism behind the mandate divide, while the re-election inventive results in cross-tier contamination. In all scenarios, Group 1 MPs are expected to be constituency oriented and more prone to dissent, while Group 3 MPs are less focused on the constituency and contribute more to party unity. 
[Figure 2 about here]

\section{The Hungarian case}

To separate the re-election and the mandate incentives, I take a closer look at the role perceptions and parliamentary behaviour of Hungarian MPs during the 2010-2014 electoral term. In 2010, a three-tier electoral system was in place with 176 MPs elected in SMDs, and 210 MPs from closed regional and national party lists. Dual candidacy is a widespread practice at the Hungarian elections. Many of the SMD candidates are also nominated on party lists (even on both the regional and national level) ${ }^{\mathrm{i}}$, which is a way for parties to secure the reelection of their most valuable politicians ${ }^{\mathrm{ii}}$. Furthermore, on average, $76 \%$ of MPs nominated in SMDs at the previous election continue to compete on the SMD tier at the next election. Therefore, although we do not know exactly what kind of mandates individual MPs intend to pursue at the next election, it is very likely that former SMD candidates will end up competing for an SMD seat.

In 2011, the new election law passed in the Hungarian parliament. From 2014 on, voters elect legislators on two tiers (SMD and closed national list tier) into a considerably smaller parliament. The number of MPs is decreased from 386 to 199, which includes a substantial cut in the number of available SMD seats (106). Candidates are still allowed to run on both the SMD and the national list tier. A big change concerns multiple office-holding: MPs in the newly elected parliament are not allowed to hold other elected (i.e. local) offices. These changes are potentially significant from the viewpoint of this study. In theory, a smaller parliament could increase the intra-party competition not only for re-election but for re- 
selection too. For SMD candidates it may facilitate constituency orientation, and at the same time a larger emphasis on party unity. ${ }^{\text {iii }}$

Due to the lack of transparency, there is limited knowledge on the Hungarian parties' candidate selection strategies. For the 2010 elections, there is only one comprehensive work which is based on a series of face-to-face interviews with party officials of four Hungarian parties (Fidesz, Jobbik, LMP and MSZP) (Marjai 2012). Although Marjai admits that the local level has strong powers in nominating candidates, in most cases national level decisionmakers can overwrite local decisions. The degree of decentralization is the highest in the case of MSZP, where the larger importance of the local level is demonstrated, with some control from the national level (Marjai, 2012, p. 49). However, the strong powers of the national party branch seems to be the rule rather than the exception. This gives Hungarian parties a considerable authority over their MPs.

Nevertheless, strong party authority does not automatically imply party-centred MP behaviour. Personalisation and constituency orientation may easily be not only the initiative of re-election seeking legislators, but an integral part of a centralized party strategy. After all, the party is also interested in increasing the vote share of its candidates. Papp and Zorgit (2016) have shown that personalisation was a party strategy at the 2010 and 2014 Hungarian election campaigns during which parties knowingly utilized the local popularity of their candidates. Thus, it is rightly expected that centralised candidate selection does not overthrow the personalisation tendencies of individual MPs. However, in the case of list MPs who are not nominated in SMDs, parties may expect ultimate party loyalty, and a willingness to carry out tasks that are not directly translated into votes (Papp 2019). 


\section{Data and variables}

The article aims at testing the effect of mandate type and SMD candidacy on the representatives' constituency orientation and the potential to dissent at roll-call votes. Both aspects are investigated through the role perception of the MPs, as well as observational data measuring the importance of constituency interests in the MPs' parliamentary work, and defection from the party line. To measure perceptions, I use the Hungarian data from the 2010 round of the Comparative Candidates Survey. Fieldwork was carried out right after the general elections. A face-to-face version of the questionnaire was utilised, which resulted in a sample of 232 representatives ${ }^{\text {iv }}$. To measure constituency orientation and dissent as behaviour, I rely on the official data published on the Hungarian Parliament's website. Parliamentary questions and the individual MPs' voting records are used to assess constituency orientation and defection in parliament.

\section{Constituency orientation: perceptions and behaviour}

To measure constituency orientation in the legislators' perceptions, the analysis utilizes the survey question 'Who do you think you represent as a Member of the Hungarian Parliament?'. To identify constituency oriented legislators categories 'my voters in my constituency' and 'my constituency' were merged into 'constituency oriented' (45.6 percent of the sample), and 'the voters of my party', 'a certain group in society' and 'all the citizens of the country' into 'not constituency oriented' (54.4 percent).

Parliamentary questions are used to tape the MPs' level of constituency orientation. Parliamentary questions offer legislators an opportunity to express their concern for local issues without having to influence legislation. They are widely used across European 
democracies to request information from the government, but also to provide information to voters on MP work and priorities (Russo and Wiberg 2010). Questions are also increasingly used by scholars to describe the MPs' policy positions (Rozenberg et al. 2011; Saalfeld 2011; Vliegenthart and Walgrave 2011) and representational focus such as constituency orientation (Chiru 2018; Martin 2011; Russo 2011).

Hungarian MPs may submit interpellations, written, oral and direct questions. Although there are differences between these four types along the lines of the form of submission ${ }^{\mathrm{v}}$ and response $^{\mathrm{vi}}$, floor time ${ }^{\mathrm{vii}}$ and party control ${ }^{\mathrm{vii}}$, in this article they are handled as a homogeneous mass of questions ${ }^{\mathrm{ix}}$. The localness of the questions was identified applying dictionary-based text analysis. Using a dictionary created from the official list of municipalities and counties ${ }^{\mathrm{x}}$, geographical names are registered in a corpus of questions submitted and/or tabled during the 2010-2014 parliament. Questions that contain an item in the dictionary ${ }^{\mathrm{xi}}$ (or any of its inflexions) are considered locally oriented ${ }^{\text {xii }}$ Questions then were aggregated to the MP-level showing the number of local questions submitted by the individual MPs ${ }^{\text {xiii }}$. The distribution of the resulting variable is shown in Figure 3 (a).

[Figure 3 about here]

\section{Voting dissent: perceptions and behaviour}

Dissent at roll-call is often viewed as an indicator of the MPs' position and role within their parties. While generally all MPs are expected to vote with the PPG, parties are more permissive towards MPs delivering a larger amount of personal vote. Depauw and Martin (2009) and Carey (2007) argue that it is the same electoral incentives (most importantly intraparty competition) that encourage legislators to seek a personal vote and to defect at roll-call. 
Similarly, Hix (2004) demonstrates that Members of the European Parliament who were elected in candidate-centred electoral systems are more likely to breach party unity than those elected under party-centred rules. Investigating the differences between SMD and list MPs in mixed-member electoral systems scholars have found that SMD MPs are more prone to dissent in Russia (Kunicova and Remington 2008), Germany (Sieberer 2010) and Hungary (Olivella and Tavits 2014).

To capture the MPs' willingness to dissent, they were asked to choose sides in hypothetical situations in which there is a conflict between the opinion of the voters, the party and the MPs themselves. The question was formulated as follows: 'How should a Member of Parliament vote in parliament if ... (1)... the voters in his/her constituency have one opinion and his/her party takes a different position, (2) .... his/her own opinion on an issue does not correspond with the party position?'. In other words, under what circumstances MPs think deserting the party line at roll-call is acceptable? 43.43 percent of the respondents would go with the party vote when the party position does not correspond with the voters' opinion, while 65.33 percent would chose the party position instead of their own.

To account for dissent at roll-call, 2465 votes on 961 bills were taken into account during the 2010-2014 parliament. Dissent is measured as the individual-level dissent ratio which is calculated using the number of votes at which the MP votes differently than her PPG, and the number of votes the MP participated at. The most frequent vote within the PPG at the given vote is considered the PPG vote ${ }^{\mathrm{xiv}}$. In the model I use the log-transformed version of the dissent ratio as dependent variable (see Figure 3 (b)).

\section{Independent variable}


To find out how mandate type (SMD/list MP) and SMD candidacy at the previous election (yes/no) interact to influence the MPs' role perceptions and activities I define a joint variable with three values: (1) SMD MPs and list MPs (2) with and (3) without SMD candidacy at the previous election $(50,25.9$ and 24.1 percent respectively). It is implicitly assumed that former SMD candidacy is an admissible proxy for future ambitions (Carman and Shephard 2007; Zittel 2012). ${ }^{\mathrm{xv}}$

\section{Control variables}

In addition to the above, the models include whether the MP was a mayor (Shugart, Valdini, and Suominen 2005; Tavits 2010), a party leader (Wahlke et al. 1962; Zittel 2012) and/or a newcomer (Fenno 1978; Norton and Wood 1990). Additionally, the ideological distance (Zittel and Gschwend 2008) between the MP and her party is taken into account ${ }^{\mathrm{xvi}}$, as well as whether the MP was selected by the party leadership as a candidate (Atmor, Hazan, and Rahat 2011; Depauw and Martin 2009; Sieberer 2010). The measure for Electoral security is borrowed from Olivella and Tavits $(2014,309)$ who defined the variable as the 'distance between the candidate's or list's vote share and the effective electoral threshold', which is calculated 0.75/(M+1) (Lijphart 1999), where $\mathrm{M}$ is the district magnitude. Regarding sociodemographics, age and gender are also included into the models.

Controlling for party affiliation and government status seems also desirable in models explaining questioning practices (Martin 2011) and dissent at roll-call (Depauw 2003; Kam 2009; Owens 2003). However, this appears problematic due to the special features of the 2010-2014 parliament, where almost all of the SMD seats (172 out of 176) belong to government parties (Fidesz and KDNP). This means that mandate type is highly collinear with the MPs' party affiliation. Out of 116 SMD MPs in the sample, 115 are affiliated with a 
government party. Party affiliation is more evenly distributed in the group of list MPs: 48 MPs are members of a government party, while 68 sit in opposition. To capture at least some of the differences between parties, I control for the MPs' perception of their parties' positions on the left-right scale. This variable significantly correlates both with party affiliation and government status, but is moderately correlated with mandate type. As a result of the high correlation between mandate type and party affiliation, the effect of mandate type incorporates differences between parties. Where this bias is expected to change conclusions, the analysis is carried out on the two sub-samples marked by the government vs. opposition distinction.

\section{Results}

While showing meaningful relationships, effects are often not significant in the statistical sense. Whereas the small sample size in the sub-groups of MPs may account for that, one also has to keep in mind that about 60 percent of the total population of MPs is sampled. With no known selection bias in the sample, sample figures may very well characterise the population of MPs even without statistical significance. Therefore, meaningful effects are also discussed in the article. ${ }^{\text {xii }}$ The following subsections focus on, first, legislators' constituency orientation, and second, voting dissent.

\section{Explaining constituency orientation}

Binary logistic regression explains legislators' constituency orientation in their role perceptions (see Supplementary Table 1(a) and Figure 4). The effect of mandate type and SMD candidacy is significant, and quite substantial. SMD MPs consider themselves constituency oriented with a probability of 0.73 , while list MPs are less likely to have clear 
constituency focus regardless of their former candidacy ( 0.24 and 0.12 probabilities respectively ${ }^{\text {xviii }}$ ). Additionally, there is no significant difference between the two groups of list $\mathrm{MPs}^{\mathrm{xix}}$. Therefore, it appears that the difference between MP groups is the consequence of the mandate type which is a clear indication of the mandate divide.

[Figure 4 about here]

As to constituency orientation in the legislators' parliamentary questioning, the number of locally relevant questions is an overdispersed count variable: a lot of MPs ask no or only a few questions, while a few MPs submit a larger number of inquiries. Hence, negative binomial regression is used to test the effect of mandate type and SMD candidacy on the localness of questions (Cameron and Trivedi 1998; Long 1997). On the one hand, as Figure 5(a) - drawn based on the model in Supplementary Table 2 - indicates, the number of local questions submitted by SMD MPs and list MPs without SMD nomination is very modest. List MPs with SMD nomination on the other hand appear to frequently bring up local issues in parliament. This result could very well confirm the superior effect of the re-election incentive in the case of list MPs.

However, keeping in mind that in 2010, almost all SMD MPs are members of Fidesz-KDNP, and therefore all list MPs with SMD nomination are from opposition parties, results may bring up a question. Do we see the dominance of list MPs with previous SMD nomination because they are also opposition MPs who try to control the government through parliamentary questions? To disentangle these two effects, the model was re-ran on the two sub-samples of government and opposition MPs. In the group of government MPs (Figure 5(b)) SMD MPs ask about 1.5 questions on average, while list MPs with no SMD nomination 
submit 0.72 inquiries. More importantly, there is no indication for the re-election incentive to have a significant effect in the opposition sub-sample ( $N=62$; Figure 5(c)): the average question asked by list MPs with SMD nomination is 22.2, whereas list MPs with no SMD nomination ask even more locally relevant questions. Hence, it seems that local questioning is not primarily a tool for the opposition to 'keep their SMD candidates in the game' by focusing on local issues, but to control the government. However, this does not mean that opposition MPs do not use local questions at all to improve their chances at the next elections.

[Figure 5 about here]

To show how opposition MPs react to strategic challenges, the model was ran on the subsample of SMD candidates including an interaction between mandate type and the electoral security of MPs. If electoral security makes a difference in how MPs utilize parliamentary questions, we may conclude that MPs strategically react to their positions within the SMDs, and thus respond to the re-election inventive. The variable Electoral margin measures the difference between SMD candidates finishing in the first and second places relative to the number of votes cast ${ }^{\mathrm{xx}}$. Small values indicate close races, while large values show the second candidate lagging behind the winner. Results presented by Figure 6 indicate that SMD MPs are not sensitive to changes in the electoral margin. SMD MPs in safe districts and those in 'close-call' districts ask the same amount of local questions. The group of list MPs interested in the SMD competition, however, are quite diverse in terms of the number of local questions. SMD candidates ask more questions in districts where they suffered a larger defeat. Thus, it seems that list MPs use local questions to try lessening the gap between them and the winners of the districts. In this sense, results indicate that the re-election incentive is very well in 
place, but only for list MPs, and government control is the key driving factor for submitting locally oriented questions.

[Figure 6 about here]

\section{Explaining voting dissent}

Now, turning to explaining maverick behaviour, Figure 7 presents the results of the binary logit models estimating the likelihood with which MPs promote to vote against the party position should it contradict with the voters' opinion and her own views. Model results are shown in Supplementary Table 1 (b)-(c).

[Figure 7 about here]

Although there are no significant differences between MP groups, results reveal interesting tendencies. In the first case (Figure 7 (a)), SMD MPs think that they should vote in congruence with the voters' opinion (the probability of willingness to dissent is 0.6 ), whereas list MPs are more willing to follow the party line $(\operatorname{Pr}=0.49$ and 0.52$)$. The figures give larger support for the effect of the mandate incentive, although it is worth noting that all three groups show relatively high levels of willingness to vote against the party.

In the second case, (Figure 7 (b)), legislators are generally less willing to dissent: SMD MPs score the lowest $(\operatorname{Pr}=0.32)$ on this dimension, which suggests that mandate motivations are not in play in this scenario. Furthermore, weakening the re-election motivation narrative, list MPs with SMD candidacy $(\operatorname{Pr}=0.37)$ are less willing to cross the party than list MPs with no SMD nomination $(\mathrm{Pr}=0.42)$. Differences between groups, however, are again not significant. 
For the estimation of individual dissent at roll-call as observed I use linear regression (see Supplementary Table 3). Differences between the three groups are statistically significant, although due to the generally high level of party unity in the Hungarian parliament, not sizeable. Interestingly, and contrary to expectations, and as shown on Figure 8 (a), SMD MPs are amongst the most disciplined. Furthermore, list MPs with SMD candidacy are more likely to dissent than those without.

When looking at roll-call votes in parliament one has to acknowledge that MPs of different parties may act in systematically different ways. To maintain the stability of governance, government parties may take party unity more seriously than opposition parties. Therefore, to see if roll-call behaviour indeed shows the patterns similar to what was presented above, one needs to analyse the behaviour of government and opposition parties separately. Figure 8 (b) and (c) show the effects of mandate type and candidacy on dissent from models run separately on the two sub-samples of government and opposition MPs. Looking at government MPs, we do not see significant differences between SMD MPs and list MPs with no SMD candidacy. On the sample level, however, SMD MPs seem more prone to dissent. In the case of opposition MPs figures indicate no significant and meaningful difference between the two types of list MPs.

[Figure 8 about here]

Finally, similar to the analysis of local questions, Electoral margin is considered in an interaction with mandate type and SMD candidacy within the group of SMD candidates to find out if MPs strategically react to their positions within their SMDs. The dissent potential 
of SMD MPs slightly increases with increasing margin: SMD MPs who are safe in their districts feel less vulnerable to de-selection by the party centre, and thus, are freer to follow other considerations at roll-call. Conversely, list MPs who lost with a big margin in the SMD are less valuable to their parties. Consequently, they must be more alert to the party's position.

[Figure 9 about here]

\section{Discussion and conclusion}

This study looks at the motivations of legislators to think and behave in a constituency oriented manner and to be willing to break party unity in parliament. The empirical part attempts to separate the re-election and the mandate incentives by investigating legislator attitudes and behaviour in a mixed-member electoral system with dual candidacy. Under such rules, it is possible to contrast the two types of motivations by comparing the behaviour of MPs holding different types of mandates as well as MPs with and without SMD candidacy. If MP behaviour forms along mandate type, it means that legislators react to the mandate incentive, while in the case of a difference between the different types of candidacies, MPs primarily respond to the re-election motivation. The article uses the 2010 Hungarian data from the Comparative Candidates Survey as well as the legislators' official activity record between 2010 and 2014. Table 1 summarizes the results of the article.

Table 1. The mandate and re-election incentives in constituency orientation and voting dissent

\begin{tabular}{llll}
\hline & & Mandate incentive & Re-election incentive \\
\hline Constituency orientation & Attitudes & Present & Not present \\
& Behaviour & Not present & Present \\
& & & \\
\hline
\end{tabular}




\begin{tabular}{llll}
\hline Voting dissent & Attitudes & Present & Not present \\
& Behaviour & Not present & Present \\
\hline
\end{tabular}

Results are far from straightforward. On the one hand, different incentives prevail in different cases. The mandate incentive strongly characterises the MPs' attitudes toward constituency orientation. MPs appear to be aware of what they were elected to do: SMD MPs tend to think they represent their constituencies, while list MPs (regardless of SMD candidacy) stand for representing other social groups. However, as to their willingness to dissent the party at rollcall, no meaningful differences are observed between the various groups of MPs.

On the other hand, contrary to the case of attitudes, the MPs' behaviour is more strategic. List MPs who are nominated in SMDs submit a larger number of local questions, and are more likely to defect the party line at roll-call, than either SMD MPs or list MPs with no SMD candidacy. To confirm that electoral incentives are indeed in play, the effect of electoral margin is taken into account in the group of SMD candidates. It is shown that SMD candidates, and especially list MPs with SMD candidacy strategically react to their positions in the district level competition. This feature of MP behaviour further underlines the reelection incentive.

Results highlight an interesting tendency in the Hungarian legislators' attitudes and behaviour. The fact that they act differently to what they think they should do uncovers a tension between the MPs' work and how it is conceived. Politics becoming professionalized, MPs must keep their seats in parliament to secure their livelihoods. However, in doing this, list MPs who want to step up and become SMD MPs must also act as SMD MPs already in their positions as list MPs, even if they feel that this is not what they should do. 
Nevertheless, the results related to the number of locally relevant questions are puzzling in a sense that although the re-election incentive is evidently present within the group of list MPs with SMD candidacy, no such conclusions are valid in the case of SMD MPs. It seems, that SMD MPs do not use parliamentary questions to convey a local message at all. This makes sense if we think about the amount of resources SMD MPs dispose of relative to list MPs: SMD MPs are able to represent local interests through more costly activities such as holding office hours in the constituency or engage in casework that, in terms of votes, probably pays better off. Conversely, list MPs have to express local concern applying less expensive methods, like parliamentary questions. As a result, list MPs who are involved into the competition for the SMD seats bring more local issues to the agenda as both SMD MPs and list MPs not running in SMDs.

As all empirical studies, this work has also its limitations. Most importantly, it is not possible to take into account all aspects of the legislators' work. Focusing only on parliamentary questions and dissent at roll-call leaves us in the dark about alternative measures MPs take to represent district interests. The danger of drawing the wrong consequences is mostly prominent in the case of SMD MP. Whereas electoral motivations appear in the case of list MPs in their questioning practices suggesting that questions indeed offer an opportunity to bring local issues to the agenda, and list MPs take it, the SMD MPs' low activity in questioning does not mean that they do not take up local issues at all. If we could observe all their activities, we may see that they behave exactly the way they think they should as constituency representatives. This possibility could further strengthen evidence for the mandate incentives, but it does not mask evidence for the mixture of two incentives already provided by this study. 


\begin{abstract}
${ }^{\text {i }}$ Between 1990 and 2010, 84.8 percent of SMD candidates were also nominated on party lists.
${ }^{\text {ii }}$ SMD candidates are systematically placed higher on party lists. Between 1990 and 2010, the relative list position (absolute list position/list length) of SMD candidates on regional and national list is significantly lower
\end{abstract} than that of list-only candidates $(\mathrm{F}=9556.4, \mathrm{p}=0.000 ; \mathrm{F}=271.44, \mathrm{p}=0.000)$.

iii The prospect of multiple office-holding to become prohibited can also change how SMD MPs act in parliament (roughly 82 percent of mayors in the sample are SMD MPs). The decreasing number of available seats mean that some SMD MPs will have to continue their careers as list MPs or as local office holders. SMD MPs might start preparing to give up their national mandates in exchange for their parties' support at the local elections. In the case of MPs retiring from national level politics, it may be expected that constituency orientation prevails both as a re-election and a mandate incentive, because this is a convenient way to build a local supporter base for the local elections.

iv The sample was randomly selected taking into account the distribution of MPs across party affiliation and mandate type. In the case of non-response, the MP was replaced by another with similar key features randomly selected from the group of MPs excluded from the initial sample. The sample represents the population of MPs with regards to party affiliation and mandate type rather well.

${ }^{\mathrm{v}}$ Interpellations, oral and written questions have to be submitted in writing, whereas direct questions are tabled without prior documentation.

${ }^{\mathrm{vi}}$ Interpellations, oral and direct questions are answered orally during the parliamentary session (each have their own schedule with fixed time limits), while written questions require written response.

vii Interpellations, oral and direct questions require floor time, hence are limited in numbers. Conversely, as not asked in session, written questions require no such limitations.

viii Naturally, the form of submission and response as well as time limitations affect how powerful each question is in controlling the government and capturing voter attention. Questions that are tabled during the sessions have the potential to receive greater attention than written questions. As these (oral) forms have also time limitations, the party centre takes up a greater role in organizing them. Contrarily, written questions capture a smaller portion of the spotlight, and are unlimited in numbers, making legislators free to use it without substantial interference from their parties. 
${ }^{\text {ix }}$ Nevertheless, to make sure that the listed differences do not condition MPs to use considerably different
approaches regarding the various questioning tools, I ran the models separately for all question types with substantively the same results.

${ }^{\mathrm{x}}$ The list was issues by the Hungarian Statistical Office (KSH). http://www.ksh.hu/apps/hntr.egyeb?p_lang=HU\&p_sablon=LETOLTES, accessed on the 21st December, 2016. xi This time, localness is not defined as mentioning issues related to the SMD of the legislator, but as mentioning any issue regarding the local level. Although the most appropriate approach would be to account for the geographical constituency, it would exclude list MPs without SMD nomination from investigation, because they have no constituency based on which questions could be coded as local. Keeping these MPs in the sample as benchmark is crucial to answering the question of the paper.

xii Although the coding of questions was fully computerised, all matches were double-checked manually. It was necessary because several municipalities have matching names with certain legislators (e.g. Varga, Semjén). Additionally, a large number of municipalities have names taken from ordinary language.

xiii Questions submitted by multiple MPs are excluded from the analysis.

${ }^{\text {xiv }}$ Admitting, that this method of measuring dissent may be subject to criticism, I also calculated an alternative measure of distance from the PPG. In this case, party positions are defined as cluster centred using k-means clustering, where the final number of clusters corresponds to the number of parties in the parliament. The normalised distance from the $P P G$ is the distance between cluster centres and the individual MPs within the cluster. In order to be able to calculate the distance measure, missing values (i.e. votes at which the MP did not participate) were imputed with the PPG vote. In the case the complete PPG was absent, abstention was coded as the PPG vote. Although this approach might be viewed problematic, imputing the PPG vote did not change distance between legislators substantially. Models using this variable as dependent show identical results with the one presented in the article. For the sake of easier interpretation, I use the individual-level dissent ratio in the analysis.

${ }^{\mathrm{xv}}$ Although at the time of the investigation list MPs may win their mandates from regional and national party lists, for sample size considerations I do not break down this group into two. Distinguishing between regional and national list MPs does not change results in groups with sufficient sample size granting estimable coefficients.

${ }^{\text {xvi }}$ Ideological distance is measured as the absolute difference between the MP's self-reported placement on the left-right scale (11 points) and the MP's assessment of the party's position. 
xvii Finite population correction (Hoyle 1999) cannot be applied in the case of models running on the various subsamples, because the sample was not randomly drawn from the respective sub-populations. Nevertheless, in several cases, corrected standard errors would allow for considering effects statistically significant.

xviii $\chi 2=27.97, p=0.000 ; \chi 2=20.04, p=0.000$

${ }^{\mathrm{xix}} \chi 2=1.51, \mathrm{p}=0.219$

${ }^{\mathrm{xx}}$ Electoral margin is a better predictor of district competition than Electoral security. The latter was used in models ran on the whole sample because it allows for the comparison of SMD and list MPs. 


\section{References}

Atmor, Nir, Reuven Y. Hazan, and Gideon Rahat. 2011. "Candidate Selection." In Personal Representation. The Neglected Dimension of Electoral Systems, ed. Josep M. Colomer. Colchester: ECPR Press, 21-36.

Baumann, Markus, Marc Debus, and Tristan Klingelhöfer. 2017. "Keeping One's Seat: The Competitiveness of MP Renomination in Mixed-Member Electoral Systems." The Journal of Politics 79(3): 979-94.

Bawn, Kathleen, and Michael F Thies. 2003. "A Comparative Theory of Electoral Incentives Representing the Unorganized Under PR, Plurality and Mixed-Member Electoral Systems." Journal of Theoretical Politics 15(1): 5-32.

Borghetto, Enrico, and Marco Lisi. 2018. "Productivity and Reselection in a Party-Based Environment: Evidence from the Portuguese Case." Parliamentary Affairs 71(4): 868-87.

Bowler, Shaun, and DAvid M. Farrell. 1993. "Legislator Shirking and Voter Monitoring: Impacts of European Parliament Electoral Systems upon Legislator - Voter Relationships." Journal of Common Market Studies 31(1): 45-70.

Bräuninger, Thomas, Martin Brunner, and Thomas Däubler. 2012. "Personal Vote-Seeking in Flexible List Systems: How Electoral Incentives Shape Belgian MPs' Bill Initiation Behaviour." European Journal of Political Research 51(5): 607-45.

Cain, Bruce, John Ferejohn, and Morris P. Fiorina. 1987. The Personal Vote: Constituency Service and Electoral Independence. Harvard University Press.

Cameron, A. Colin, and Pravin K. Trivedi. 1998. Regression Analysis of Count Data. Cambridge: Cambridge University Press.

Carey, J.M., and M.S. Shugart. 1995. "Incentives to Cultivate a Personal Vote: A Rank Ordering of Electoral Formulas." Electoral Studies 14(4): 417-39.

Carey, John M. 2007. “Competing Principals, Political Institutions, and Party Unity in Legislative Voting." American Journal of Political Science 51(1): 92-107.

Carman, Christopher, and Mark Shephard. 2007. "Electoral Poachers? An Assessment of Shadowing Behaviour in the Scottish Parliament." The Journal of Legislative Studies 13(4): 483-96.

Chiru, Mihail. 2018. "The Electoral Value of Constituency-Oriented Parliamentary Questions in Hungary and Romania." Parliamentary Affairs 71(4): 950-69.

Cooper, Christopher A, and Lilliard E Richardson. 2006. "Institutions and Representational Roles in American State Legislatures." State Politics \& Policy Quarterly 6(2): 174-94.

Cox, Karen E, and Leonard J Schoppa. 2002. "Interaction Effects in Mixed-Member Electoral Systems." Comparative Political Studies 35(9): 1027-53.

Crisp, Brian F. 2007. "Incentives in Mixed-Member Electoral Systems." Comparative Political Studies 40(12): 1460-85. 
Curtice, John, and Phillips Shively. 2009. "Who Represents Us Best? One Member or Many?" In HansDieter Klingemann (Ed.) The Comparative Study of Electoral Systems, Oxford: Oxford University Press, 171-92.

Däubler, Thomas, Love Christensen, and Lukáš Linek. 2018. "Parliamentary Activity, Re-Selection and the Personal Vote. Evidence from Flexible-List Systems." Parliamentary Affairs 71(4): 930-49.

Depauw, Sam. 2003. "Government Party Discipline in Parliamentary Democracies: The Cases of Belgium, France and the United Kingdom in the 1990s." The Journal of Legislative Studies 9(4): 130-46.

Depauw, Sam, and Shane Martin. 2009. "Legislative Party Discipline and Cohesion in Comparative Perspective." In D. Giannetti \& K. Benoit (Eds.) Intra-Party Politics and Coalition Governments, London, New York: Routledge, 103-20.

Fearon, James. 1999. "Electoral Accountability and the Control of Politicians: Selecting Good Types versus Sanctioning Poor Performance." In Adam Przeworski, Susan C. Stokes and Bernard Manin (Eds.) Democracy, Accountability, and Representation, New York: Cambridge University Press.

Fenno, Richard F. 1978. Home Style: House Members in Their Districts. Glenview, IL: Longman.

Ferrara, Federico, and Erik S Herron. 2005. "Going It Alone? Strategic Entry under Mixed Electoral Rules." American Journal of Political Science 49(1): 16-31.

Gallagher, Michael, and Ian Holliday. 2003. "Electoral Systems, Representational Roles and Legislator Behaviour: Evidence from Hong Kong." New Zealand Journal of Asian Studies 5(1): 107-20.

Heitshusen, Valerie, Garry Young, and David M. Wood. 2005. "Electoral Context and MP Constituency Focus in Australia, Canada, Ireland, New Zealand, and the United Kingdom." American Journal of Political Science 49(1): 32-45.

Herron, Eric S., and Misa Nishikawa. 2001. "Contamination Effects and the Number of Parties in Mixed-Superposition Electoral Systems." Electoral Studies 20(1): 63-86.

Herron, Erik S. 2002. "Electoral Influences on Legislative Behavior in Mixed-Member Systems: Evidence from Ukraine's Verkhovna Rada." Legislative Studies Quarterly 27(3): 361-82.

Hix, Simon. 2004. "Electoral Institutions and Legislative Behavior: Explaining Voting Defection in the European Parliament." World Politics 56(2): 194-223.

Hoyle, Rick H. 1999. Statistical Strategies for Small Sample Research. 1 edition. Thousand Oaks, Calif: SAGE Publications, Inc.

Ishiyama, John. 2000. "Candidate Recruitment, Party Organisation and the Communist Successor Parties: The Cases of the MSzP, the KPRF and the LDDP." Europe-Asia Studies 52(5): 875-96.

Kam, Christopher J. 2009. Party Discipline and Parliamentary Politics. Cambridge: Cambridge University Press.

Klingemann, Hans-Dieter, and Bernard Wessels. 2001. "The Political Consequence of Germany's Mixed-Member System: Personalization at the Grass Roots?" In Mixed-Member Electoral 
Systems. The Best of Both Worlds?, eds. Matthew S. Shugart and Martin P. Wattenberg. Oxford: Oxford University Press, 279-96.

Kunicova, Jana, and Thomas Frederick Remington. 2008. "Mandates, Parties and Dissent Effect of Electoral Rules on Parliamentary Party Cohesion in the Russian State Duma, 1994-2003." Party Politics 14(5): 555-74.

Lancaster, Thomas D. 1986. "Electoral Structures and Pork Barrel Politics." International Political Science Review 7(1): 67-81.

Lancaster, Thomas D., and W. David Patterson. 1990. "Comparative Pork Barrel Politics: Perceptions from the West German Bundestag." Comparative Political Studies 22(4): 458-77.

Lijphart, Arend. 1999. Patterns of Democracy: Government Forms and Performance in Thirty-Six Countries. New Haven: Yale University Press.

Long, J. Scott. 1997. Regression Models for Categorical and Limited Dependent Variables. SAGE Publications, Inc.

Lundberg, Thomas Carl. 2006. "Second-Class Representatives? Mixed-Member Proportional Representation in Britain." Parliamentary Affairs 59(1): 60-77.

Manow, Philip. 2013. "Mixed Rules, Different Roles? An Analysis of the Typical Pathways into the Bundestag and of MPs' Parliamentary Behaviour." The Journal of Legislative Studies 19(3): 287-308.

Mansbridge, Jane. 2009. "A 'Selection Model' of Political Representation." Journal of Political Philosophy 17(4): 369-398.

Marangoni, Francesco, and Federico Russo. 2018. "Not All Roads Lead to Rome: The Conditional Effect of Legislative Activity on Reselection Prospects in Italy." Parliamentary Affairs 71(4): 888-907.

Marjai, Erzsébet. 2012. "Candidate Selection Patterns in the 2010 Hungarian Parliamentary Elections." MA-thesis. Central European University.

Martin, Shane. 2011. "Using Parliamentary Questions to Measure Constituency Focus: An Application to the Irish Case." Political Studies 59(2): 472-88.

Mayhew, David R. 1974. Congress: The Electoral Connection, Second Edition. Yale University Press.

Mitchell, Paul. 2000. "Voters and Their Representatives: Electoral Institutions and Delegation in Parliamentary Democracies." European Journal of Political Research 37(3): 335-51.

Montgomery, Kathleen A. 1999. "Electoral Effects on Party Behavior and Development." Party Politics 5(4): 507-23.

Morlang, Diana. 1999. Socialists Building Capitalism: The Hungarian Socialist Party and Economic Policy Making. Duke University.

Norris, Pippa. 2000. "The Twilight of Westminster? Electoral Reform and Its Consequences." Political Studies 49(5): 877-900. 
-- - 2004. Electoral Engineering: Voting Rules and Political Behavior. Cambridge: Cambridge University Press.

Norton, Philip. 2002. "Introduction: Linking Parliaments and Citizens." In Philip Norton (Ed.) Parliaments and Citizens in Western Europe, London: Frank Cass, 1-18.

Norton, Philip, and David Wood. 1990. "Constituency Service by Members of Parliament: Does It Contribute to a Personal Vote?" Parliamentary Affairs 43(2): 196-208.

Olivella, Santiago, and Margit Tavits. 2014. "Legislative Effects of Electoral Mandates." British Journal of Political Science 44(2): 301-321.

Owens, John E. 2003. "Explaining Party Cohesion and Discipline in Democratic Legislatures: Purposiveness and Contexts." The Journal of Legislative Studies 9(4): 12-40.

Papp, Zsófia. 2019. "Same Species, Different Breed: The Conditional Effect of Legislator Activities in Parliament on Re-Selection in a Mixed-Member Electoral System." Parliamentary Affairs 72(1): 59-75.

Papp, Zsófia, and Federico Russo. 2018. "Parliamentary Work, Re-Selection and Re-Election: In Search of the Accountability Link." Parliamentary Affairs 71(4): 853-67.

Papp, Zsófia, and Burtejin Zorigt. 2016. "Party-Directed Personalisation: The Role of Candidate Selection in Campaign Personalisation in Hungary." East European Politics 32(4): 466-86.

Pekkanen, Robert, Benjamin Nyblade, and Ellis S. Krauss. 2006. "Electoral Incentives in MixedMember Systems: Party, Posts, and Zombie Politicians in Japan." American Political Science Review 100(02): 183-93.

Pilet, Jean-Benoit, André Freire, and Olivier Costa. 2012. "Ballot Sturcture, District Magnitude and Constituency-Orientation of MPs in Proportional Representation and Majority Electoral Systems." Representation 48(4): 359-72.

Rozenberg, Olivier et al. 2011. "Not Only a Battleground: Parliamentary Oral Questions Concerning Defence Policies in Four Western Democracies." The Journal of Legislative Studies 17(3): 34053.

Russo, Federico. 2011. "The Constituency as a Focus of Representation: Studying the Italian Case through the Analysis of Parliamentary Questions." The Journal of Legis/ative Studies 17(3): 290-301.

Russo, Federico, and Matti Wiberg. 2010. "Parliamentary Questioning in 17 European Parliaments: Some Steps towards Comparison." The Journal of Legislative Studies 16(2): 215-32.

Saalfeld, Thomas. 2011. "Parliamentary Questions as Instruments of Substantive Representation: Visible Minorities in the UK House of Commons, 2005-10." The Journal of Legislative Studies 17(3): 271-89.

Scholl, Edward L. 1986. "The Electoral System and Constituency-Oriented Activity in the European Parliament." International Studies Quarterly 30(3): 315-32. 
Shugart, Matthew S., Melody Ellis Valdini, and Kati Suominen. 2005. "Looking for Locals: Voter Information Demands and Personal Vote-Earning Attributes of Legislators under Proportional Representation." American Journal of Political Science 49(2): 437-49.

Sieberer, Ulrich. 2010. "Behavioral Consequences of Mixed Electoral Systems: Deviating Voting Behavior of District and List MPs in the German Bundestag." Electoral Studies 29(3): 484-96.

Stratmann, Thomas, and Martin Baur. 2002. "Plurality Rule, Proportional Representation, and the German Bundestag: How Incentives to Pork-Barrel Differ across Electoral Systems." American Journal of Political Science 46(3): 506-14.

Strøm, Kaare. 1997. "Rules, Reasons and Routines: Legislative Roles in Parliamentary Democracies." The Journal of Legislative Studies 3(1): 155-74.

Tavits, Margit. 2010. "Effect of Local Ties On Electoral Success and Parliamentary Behaviour The Case of Estonia." Party Politics 16(2): 215-35.

Thames, Frank C. 2001. "Legislative Voting Behaviour in the Russian Duma: Understanding the Effect of Mandate." Europe-Asia Studies 53(6): 869-84.

Thames, Frank C. 2005. "A House Divided Party Strength and the Mandate Divide in Hungary, Russia, and Ukraine." Comparative Political Studies 38(3): 282-303.

Vliegenthart, Rens, and Stefaan Walgrave. 2011. "Content Matters: The Dynamics of Parliamentary Questioning in Belgium and Denmark." Comparative Political Studies: 0010414011405168.

Wahlke, John C., Heinz Eulau, William Buchanan, and LeRoy C. Ferguson. 1962. The Legislative System. Explorations in Legislative Behavior. New York: Wiley.

Ward, Leigh J. 1998. "'Second-Class MPs'? New Zealand's Adaptation to Mixed-Member Parliamentary Representation." Political Science 49(2): 125-52.

Zittel, Thomas. 2012. "Legislators and Their Representational Roles: Strategic Choices or Habits of the Heart?" In Magnus Blomgren and Olivier Rozenberg (Eds.) Parliamentary Roles in Modern Legislatures, London: Routledge, ECPR, 101-21.

Zittel, Thomas, and Thomas Gschwend. 2008. "Individualised Constituency Campaigns in MixedMember Electoral Systems: Candidates in the 2005 German Elections." West European Politics 31(5): 978-1003. 
Figure 1. Reasons why legislators carry out casework in 15 European countries

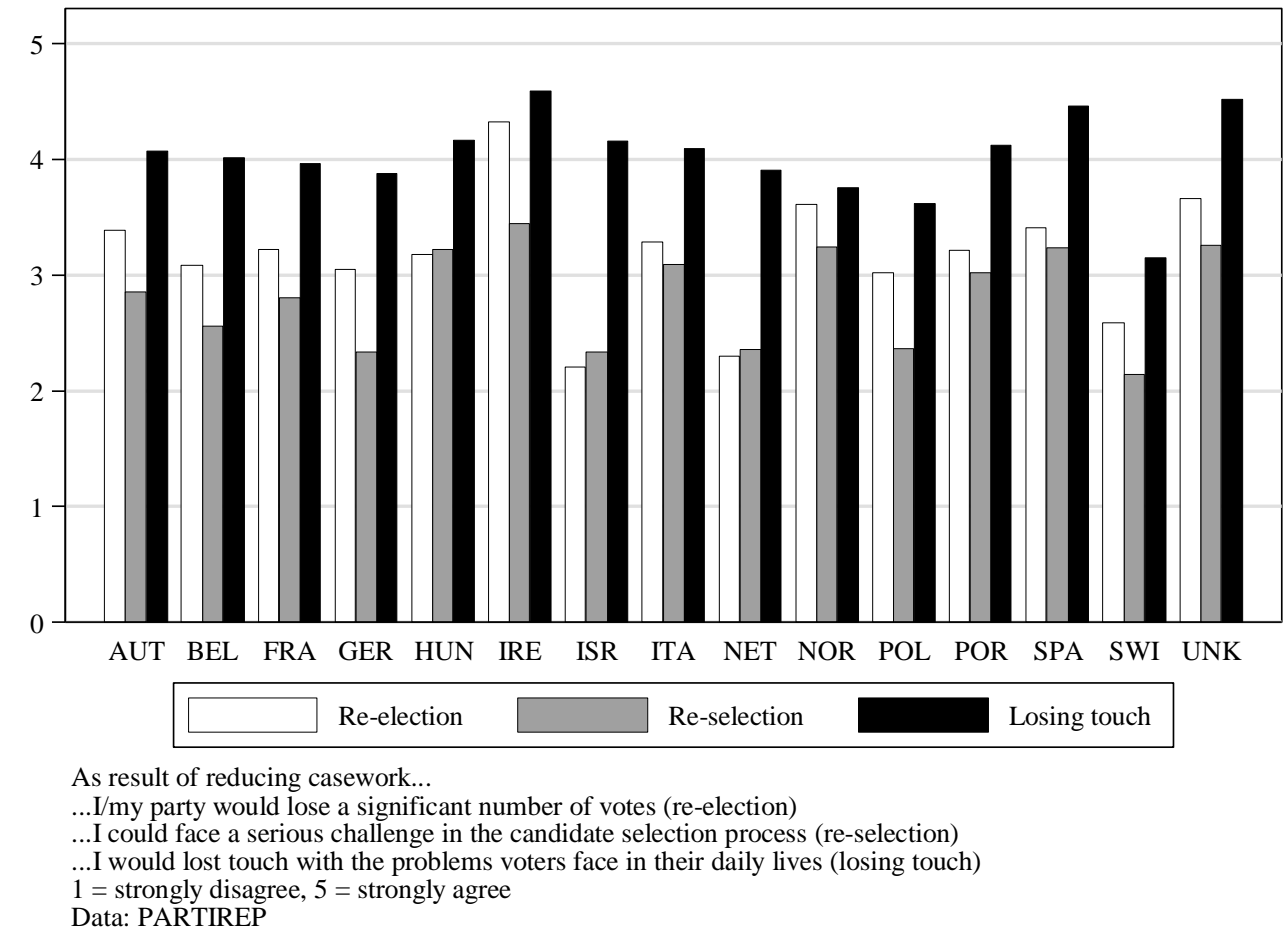


Figure 2. An expected realization of the re-election and the incumbency incentive
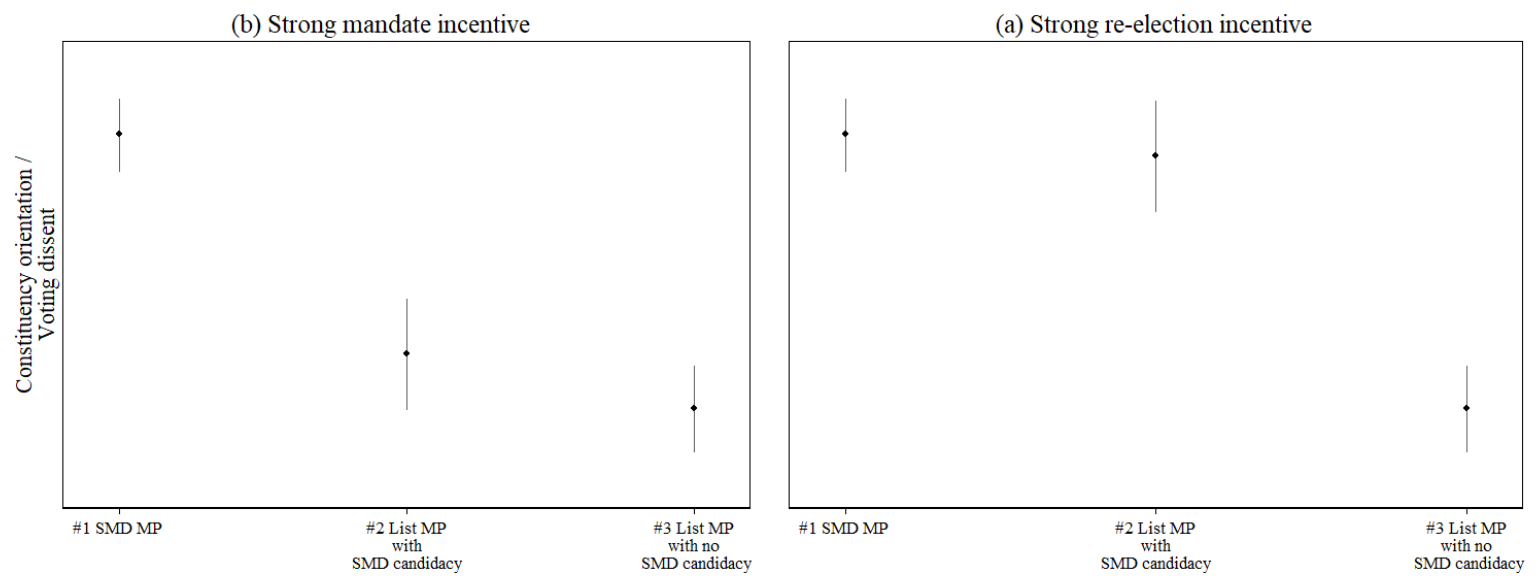
Figure 3. The Kernel density estimation of the number of local questions and individual dissent at roll-call

(a)

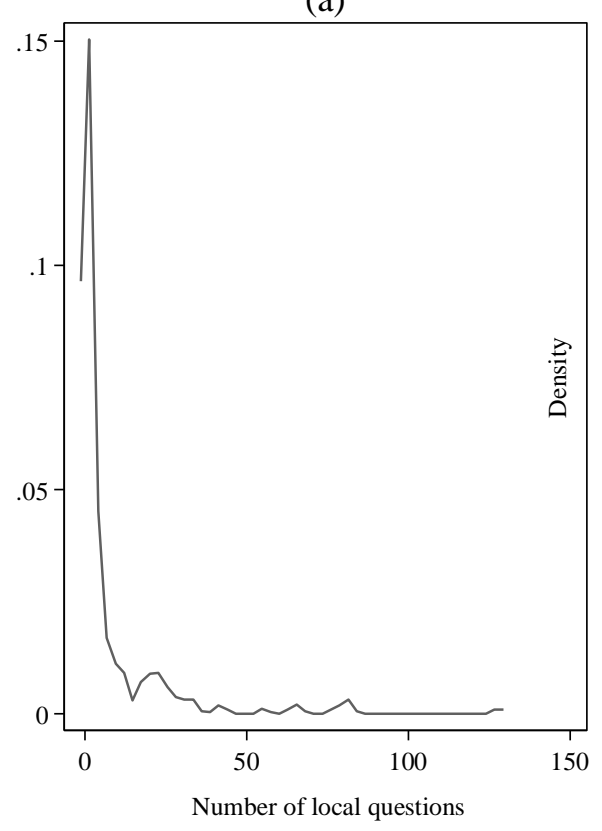

Mean $=7.4, \mathrm{SD}=16.3$ (b)

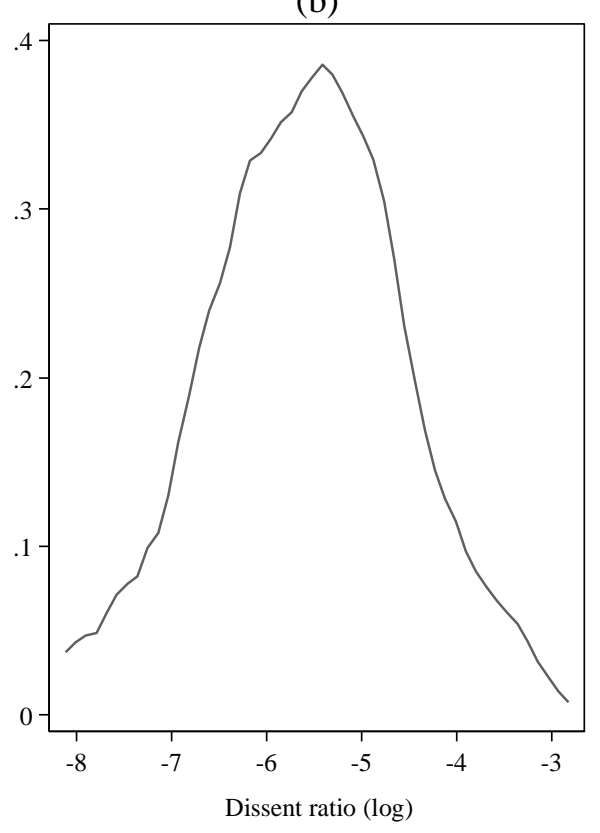

Mean $=-5.58, \mathrm{SD}=1.00$ 
Figure 4. The predicted probabilities of constituency orientation across mandate type and SMD candidacy at the next election (CI: $95 \%$ )

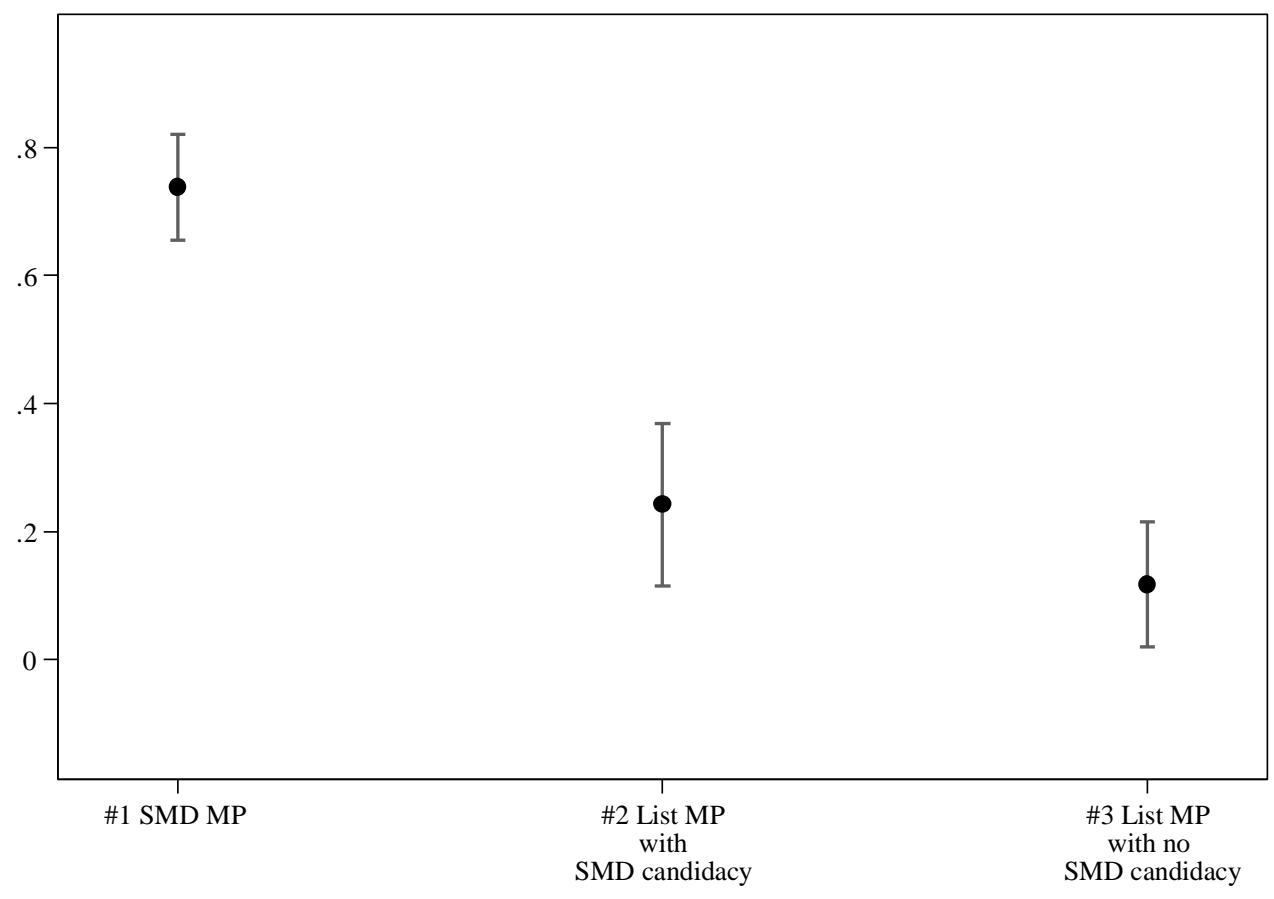


Figure 7. The predicted probabilities of the willingness to dissent (CI: $95 \%$ )

(a)

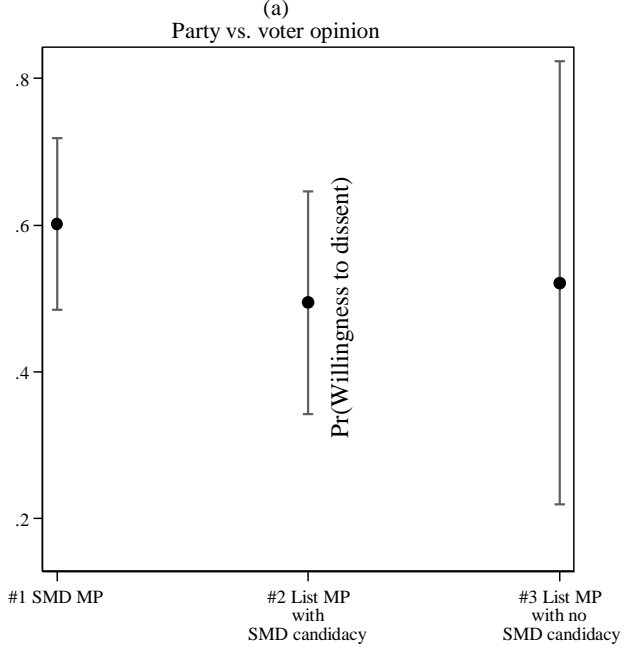

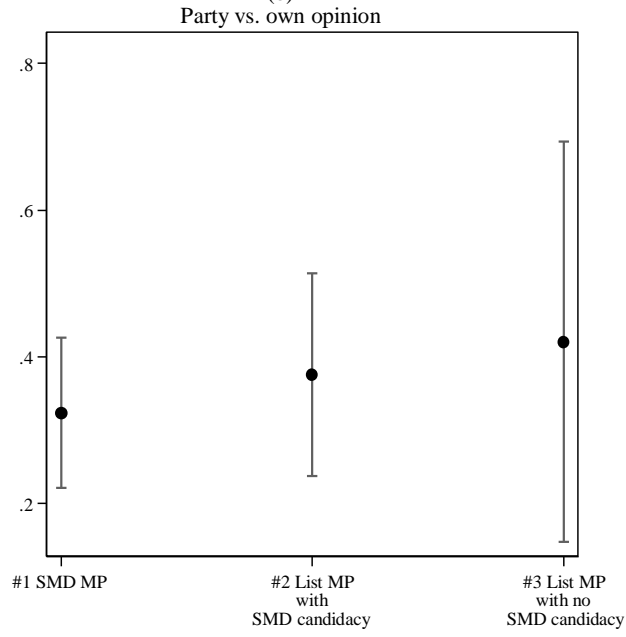


Figure 5. The estimated number of local questions across mandate type and SMD candidacy

(CI: $95 \%)$

(a) All MPs

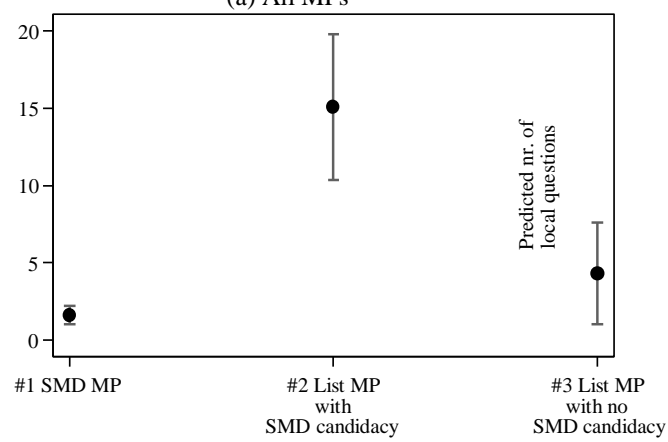

(c) Opposition MPs

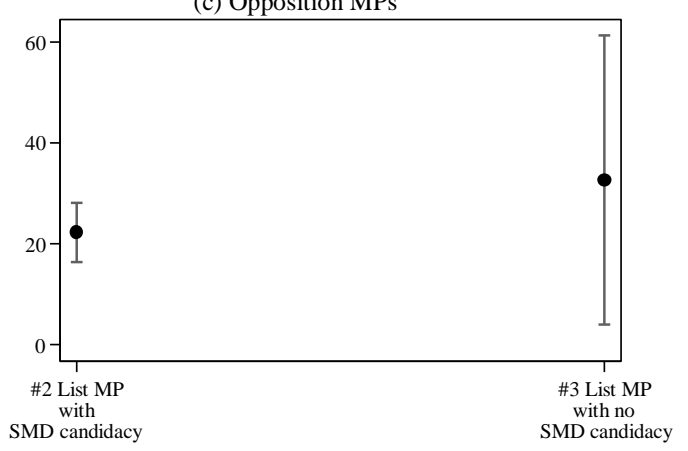

(b) Government MPs

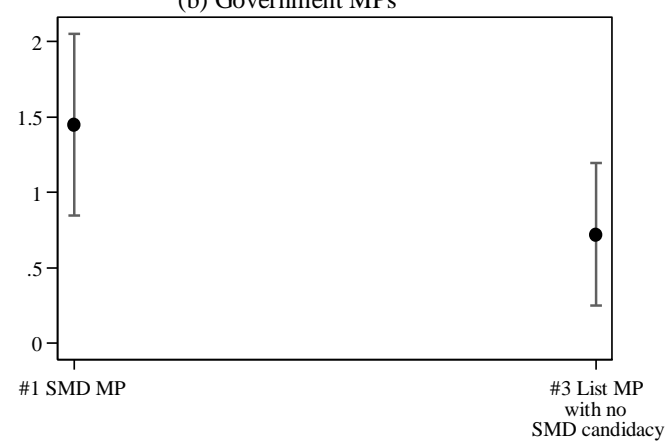


Figure 6 . The predicted number of local questions over electoral margin across mandate type and SMD candidacy (CI: $95 \%)$

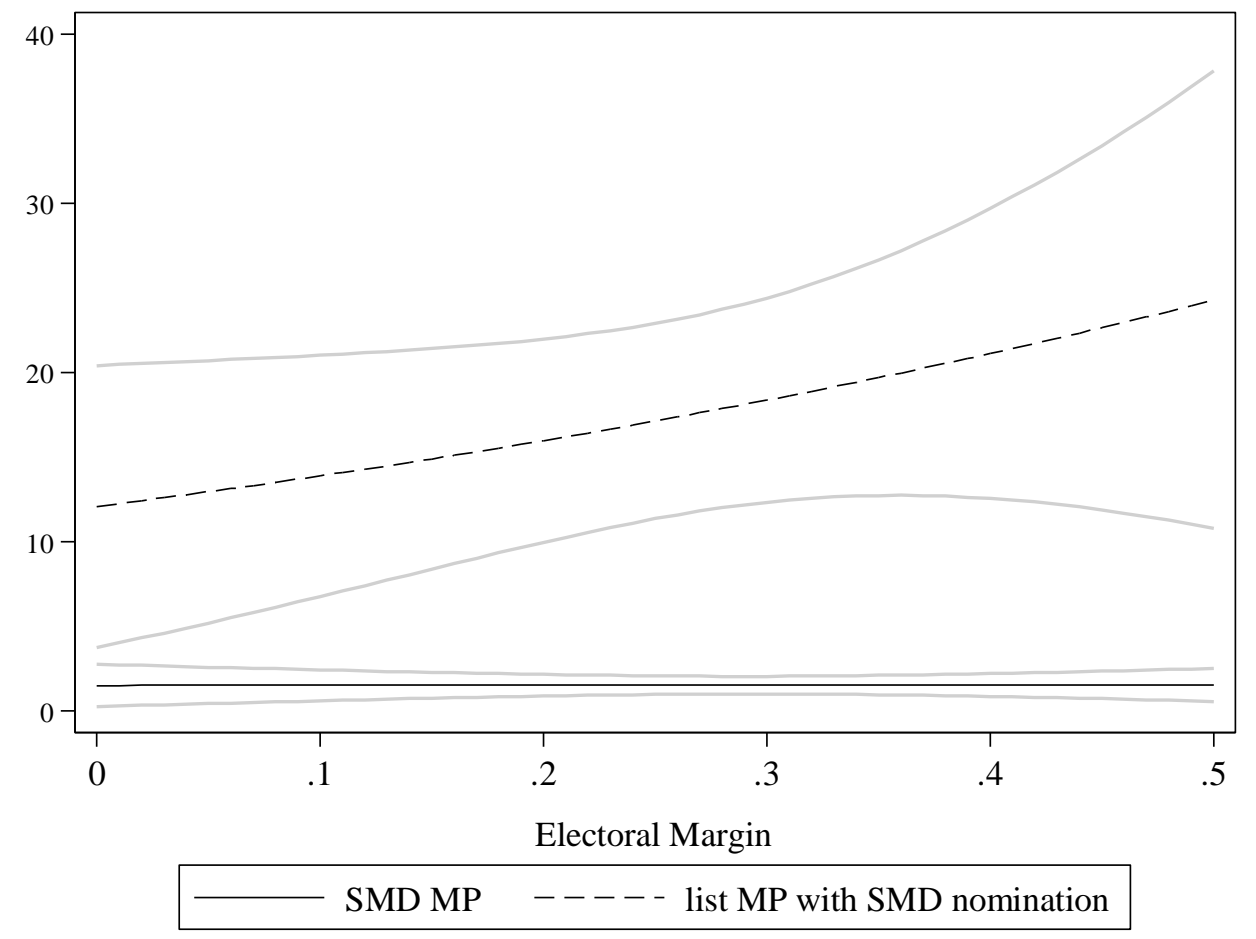


Figure 8 . The expected values of the logged dissent ratio across mandate type and SMD candidacy (CI: $95 \%)$

(a) All MPs

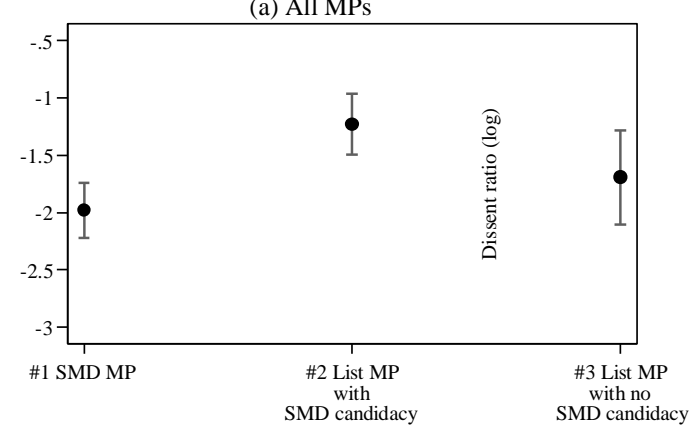

(c) Opposition MPs

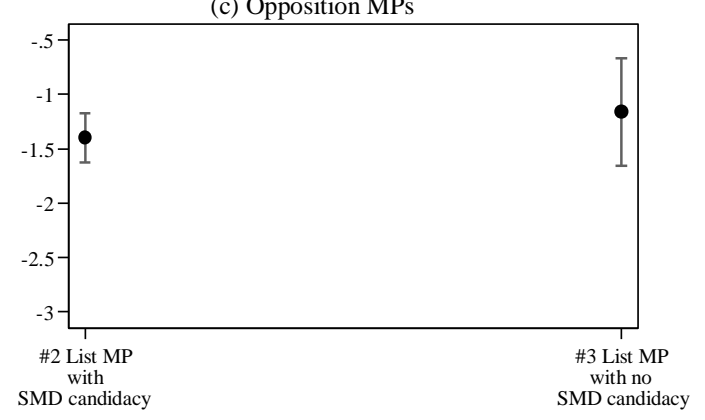

(b) Government MPs

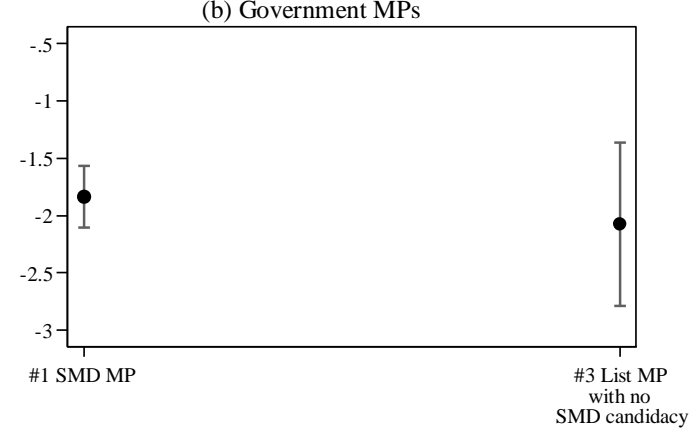


Figure 9. The expected values of the logged dissent ratio over electoral margin across mandate type and SMD candidacy (CI: $95 \%)$

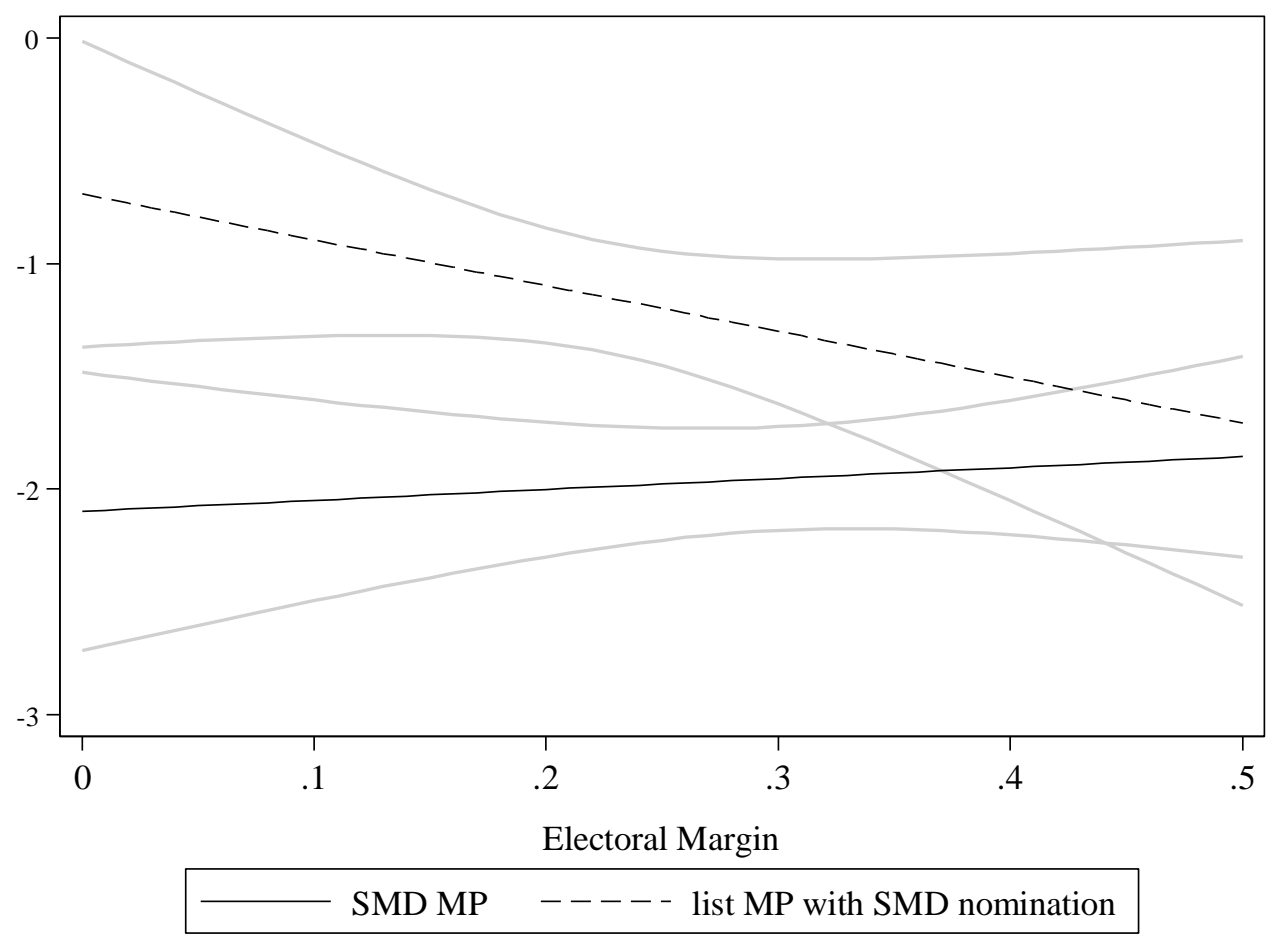

